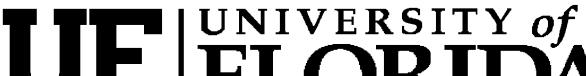 FLORIDA \\ IFAS Extension
}

\section{YOU and YOUR CREDIT: Credit Reports ${ }^{1}$}

\author{
Michael S. Gutter, Joan P. Elmore, and Travis P. Mountain ${ }^{2}$
}

Below are links to each of the YOU and YOUR CREDIT series.

Credit Dos and Don'ts: PDF version - http://edis.ifas.ufl.edu/pdffiles/FY/FY106400.pdf

Credit Card Basics: PDF version - http://edis.ifas.ufl.edu/pdffiles/FY/FY106500.pdf

Managing Your Credit: PDF version - http://edis.ifas.ufl.edu/pdffiles/FY/FY106700.pdf

Credit Scores: PDF version - http://edis.ifas.ufl.edu/pdffiles/FY/FY106800.pdf

Home Ownership and Credit: PDF version - http://edis.ifas.ufl.edu/pdffiles/FY/FY106900.pdf

Further Resources: PDF version - http://edis.ifas.ufl.edu/pdffiles/FY/FY107000.pdf

Series of Five Parts, Bound as Single Document: PDF version -

http://edis.ifas.ufl.edu/pdffiles/FY/FY107100.pdf

1. This document is FCS7232, one of a series of the Department of Family, Youth, and Community Sciences, Florida Cooperative Extension Service, Institute of Food and Agricultural Sciences, University of Florida. Original publication date September 22, 2008. Visit the EDIS Web site at http://edis.ifas.ufl.edu. 2. Michael S. Gutter, Financial Management State Specialist and Assistant Professor, Department of Family, Youth, and Community Sciences, Institute of Food and Agricultural Sciences, University of Florida, Gainesville, Florida 32611; Joan P. Elmore, Extension Agent IV, Jackson County Extension, Marianna, Florida 32448; and, Travis P. Mountain, Lecturer, Department of Family, Youth, and Community Sciences, Institute of Food and Agricultural Sciences, University of Florida, Gainesville, Florida 32611

The Institute of Food and Agricultural Sciences (IFAS) is an Equal Opportunity Institution authorized to provide research, educational information and other services only to individuals and institutions that function with non-discrimination with respect to race, creed, color, religion, age, disability, sex, sexual orientation, marital status, national origin, political opinions or affiliations. U.S. Department of Agriculture, Cooperative Extension Service, University of Florida, IFAS, Florida A. \& M. University Cooperative Extension Program, and Boards of County Commissioners Cooperating. Larry Arrington, Dean 


\section{YOU and YOUR CREDIT: Credit Reports ${ }^{1}$}

Michael S. Gutter, Financial Management State Specialist, IFAS/UF, Joan P Elmore, Extension Agent IV, Jackson County Extension, Marianna, Florida 32448, Travis P. Mountain, Lecturer, IFAS/UF ${ }^{2}$

\section{CREDIT REPORT BASICS}

Whether or not you are considering making a major financial move, it's a good idea to check your credit report. It is best to find out if you have a credit problem before you need credit! That way you can be aware of and take care of problems before they jump up and derail your plans. If you've made mistakes in paying previous loans, made late payments, or had other problems, you may still be able to reduce the amount of damage they will do to your credit by explaining special circumstances to the potential lender, especially for major installment loans.

\section{FREE CREDIT REPORT}

The Fair Credit Reporting Act (FCRA) and the 2003 amendment known as the Fair and Accurate Credit Transactions Act (FACT Act or FACTA) which gives you the rights to:

- learn what your credit record contains

- correct inaccurate or incomplete information

- obtain a free credit report every twelve months from each of the three nationwide consumer credit reporting agencies (CRAs) —Experian, TransUnion, and Equifax.
Under FACTA, consumers are able to access their credit report via mail, telephone, or through the government-authorized website, annualcreditreport.com.

The three credit bureaus are:

Equifax

P.O. Box 740241

Atlanta, GA 30374

1-800-685-1111

www.equifax.com

TransUnion

P.O. Box 1000

Chester, PA 19022

$1-800-888-4213$

or $1-800-916-8800$

www.transunion.com

Experian

P.O. Box 2104

Allen, TX 75013

1-888-397-3742

www.experian.com

When you request your credit report, you will need to provide your full name (including birth name), spouse's name, Social Security number, date of birth, and complete addresses for the past five years. You will also be asked security questions to prove that you are who you say you are to avoid identity theft issues.

1. This document is FCS7232, one of a series of the Department of Family, Youth and Community Sciences, Florida Cooperative Extension Service, Institute of Food and Agricultural Sciences, University of Florida. First published: September 2008. Please visit the EDIS Web site at http://edis.ifas.ufl.edu.

2. Michael S. Gutter, Financial Management State Specialist, IFAS/UF, Joan P Elmore, Extension Agent IV, Jackson County Extension, Marianna, Florida 32448, Travis P. Mountain, Lecturer, IFAS/UF. 
Credit Reports
An example of such a question could look like, "What is the account numbers for three current credit cards"

It is important to note that with these free credit reports, you will not receive an actual score, often referred to as a credit score or a FICO (Fair Isaacs \& Company) score. Through annualcreditreport.com however, you can access your score for a small nominal fee. Make sure your report is accurate before paying for your score.

\section{CREDIT REPORT OUTLINE}

A credit report consists of four basic sections:

- Identifying information

- Public records

- Credit history

- Inquiries

Identifying Information is just thatinformation to identify you. Look at it closely to make sure it is accurate. Other information might include your current and previous addresses, date of birth, telephone numbers, driver's license number, your employer and your spouse's name.

Public Record: This includes information in public records such as judgments, bankruptcies and other court proceedings of a financial nature, tax liens.

Credit History: Each account will include the name of the creditor and the account number. You may have more than one account from a creditor; if you move, they transfer your account to a new location and assign a new number. When you open an account, the kind of credit (installment, mortgage, car loan, or revolving, store credit card) is reported. It includes:
- Name under which the account is listed (your name or jointly with another person), total amount of the loan, credit limit, and highest balance on the card

- How much you owe and how well you've paid the account

- Status of the account (open, inactive, closed, paid, etc.)

On Experian's credit report, your payment history is written in plain English with phrases such as "never pays late," "typically pays 30 days late," etc. "Charged off” means the creditor has given up.

Inquiry: The report provides a list of everyone who has asked to see your credit report. Inquiries are divided into two sections:

- Hard inquiries are ones you initiated by filling out a credit application. The more inquiries of this type, the more potential debt.

- Soft inquiries are from companies that want to send out promotional information to a pre-qualified group or from current creditors who are monitoring your account.

Certain types of inquiries actually lower your credit score. Inquiries that can decrease your FICO score are the ones that come from creditors who you have asked for new or more credit.

\section{CORRECTING BILLING ERRORS}

The Fair Credit Billing Act requires creditors to correct errors promptly and 
\begin{tabular}{l|l} 
Credit & YOU and YOUR CREDIT \\
Reports &
\end{tabular}

without damage to your credit rating. The law defines a billing error as:

- Something you didn't buy.

- Something that is not properly identified on your bill or is for a different amount.

- Something that you did not accept on delivery or that was not delivered.

- Arithmetic errors.

- Bills not to your current address, if you told the creditor about an address change at least 20 days before the end of the billing period. The process takes time-Creditors have 30 days to respond to the discrepancy.

When a charge is in dispute, then that dispute will show up on your report. Experienced lenders say it's common for reports to have errors. Some estimate that as many as 80 percent of all credit reports have some kind of misinformation. Any error that you find must be investigated by the credit bureau with the creditor who supplied the data.

The credit bureau will remove from your credit report any errors a creditor admits are there. If you disagree with the findings, you can file a short statement (sample form included) in your report giving your side of the story. Future reports to creditors must include this statement or a summary of it. Once you have written about a possible error, a creditor must not give out information to other creditors or credit bureaus that would hurt your credit reputation until the matter is resolved. And, until your complaint is answered, the creditor may not take any action to collect the disputed amount while the investigation is ongoing. 
Credit

Reports

\section{SAMPLE CREDIT REPORT}

\section{PERSONAL INFORMATION}

Date of Report: 6/01/2008

Name:

Social Security \#:

Date of Birth:

Current Address:

Previous Address:

Current Employer(s):

Previous Employer(s):

\section{Open Accounts 5}

Payment History

2 - 30 days late; 1 - 60 days late

\section{PUBLIC INFORMATION}

Satisfied Judgment Date Filed 11/96 Miami-Dade County Ref/Case \# 027739

Defendant: Consumer; Plaintiff: Morthsun Credit; $\quad$ Amount \$2,103; Satisfied 02/97

CURRENT ACCOUNT INFORMATION

$\begin{array}{llcccc}\text { Company Name } & \text { Account \# } & \text { Credit Limit } & \text { Date Opened } & \text { Status } & \text { Balance } \\ \text { Credit Union Savings } & 1268855 & \text { individual } & 06 / 20 / 87 & \text { Good Standing } & 3650.20\end{array}$

$\begin{array}{llcllr}\text { CREDIT ACCOUNT INFORMATION } & & & \\ \text { Company Name } & \text { Account \# } & \text { Credit Limit } & \text { Date Opened } & \text { Status } & \text { Balance } \\ \text { Credit Max } & 676741 & \$ 3000 & 01 / 05 / 99 & \text { Past Due } & 331.97 \\ \text { Gas Card Company } & 32281 & \$ 1000 & 06 / 98 & \text { Current } & 24.20\end{array}$

\begin{tabular}{|c|c|c|c|c|c|}
\hline Company Name & Account \# & Credit Limit & Date Opened & Status & Balance \\
\hline Depart Store & 7789003 & $\$ 1500$ & $01 / 05 / 99$ & Closed 03/16/99 & 0.00 \\
\hline
\end{tabular}

REQUEST FOR YOUR CREDIT HISTORY

\begin{tabular}{llll}
\hline Company Name & Date Requested & Company Name & Date Requested \\
Credit See & $02 / 15 / 03$ & Home Build Stored, Inc. & $09 / 06 / 02$ \\
New Gas Co & $09 / 26 / 02$ & Banc Nine & $08 / 29 / 02$
\end{tabular}

INQUIRIES

Date Requested 08/06/00

$03 / 01 / 01$
Company Name

Bureau Disclosure

Bank card
Date Requested 12/27/01

$1 / 23 / 01$
Company Name

Department Store

Bank card 
Credit

Reports

\section{SAMPLE REQUEST FOR ADDITIONAL CREDIT REPORT}

To: (Write the address for the credit bureau’s name and address.)

I am writing to request a copy of my credit report. (Check one.)

I have been rejected for credit in the past 60 days. A copy of the letter refusing me credit is enclosed. Please send me a free report.

I am enclosing a check or money order for \$

(Required information)

My full name is

My social security number is

My home address is

To show my address, I have enclosed a photocopy of (Check one.)

driver's license or state ID card.

utility bill or credit card bill mailed to my home address.

(Complete only the items that apply to you.)

I have also lived at these addresses in the past 5 years:

My spouse's name is

I may have also had credit under these names:

Signature (required) 
\begin{tabular}{l|l} 
Credit & YOU and YOUR CREDIT \\
Reports &
\end{tabular}

\section{SAMPLE DISPUTE LETTER}

Date

Your Name

Current Address

City, State, Zip Code

Complaint Department

Credit Bureau Credit Information Services

Address

City, State and Zip

Dear Sir:

I am writing to dispute the following information in my file. The items I dispute also are circled on the attached copy of the credit report I received.

The lien filed on 09/2/95 and bankruptcy filed 10/94 are inaccurate because I never had a lien or bankruptcy filed. I am requesting that these items be deleted to correct the information.

Please investigate these matters and delete the disputed items as soon as possible.

Sincerely,

Your Name

Enclosures: Credit report copy 
\begin{tabular}{l|l} 
Credit & YOU and YOUR CREDIT \\
Reports &
\end{tabular}

\section{SAMPLE CREDIT COMPLAINT FORM}

Name:

Date:

Address:

City/State/Zip:

Daytime Telephone:

Bank/Creditor

Account Number

Address:

City/State/Zip:

Complaint involves:

Checking account

Credit Report

Loan/Auto Loan
Collection agency
Credit Union Savings Account

Credit Card

Department store charge Other

I have not tried to resolve this complaint directly with those involved.

I have tried to resolve this complaint directly with those involved.

The name of the person contacted is:

Date:

Telephone:

My complaint (describe briefly, use dates, names, etc. and also enclose copies of documentation) 
\begin{tabular}{l|l} 
Credit & YOU and YOUR CREDIT \\
Reports &
\end{tabular}

\section{SAMPLE FORM LETTER}

Re: Credit Report error
Dear Sir or Madam:
I have discovered inaccurate information on my credit report maintained by

(Credit agency name)

The report is in my name, and my Social Security number is

Enclosed, please find a copy of my credit report containing the mistaken data. I have highlighted the errors. Specifically, the following information is incorrect:

Company name:

Account number:

Incorrect information:

This is incorrect because:

Please investigate the matter with the creditor in question and should you find there is an error, when confirmed, please remove this error from my credit report.

In addition, please make this letter a permanent part of my credit report.

If you have any question about my request or the credit information in question, please do not hesitate to call me at

Thank you for your prompt attention to my request.

Your Signature

Your Typed Name

Your Address

City, State and Zip Code

Enclosure: copy of credit report 